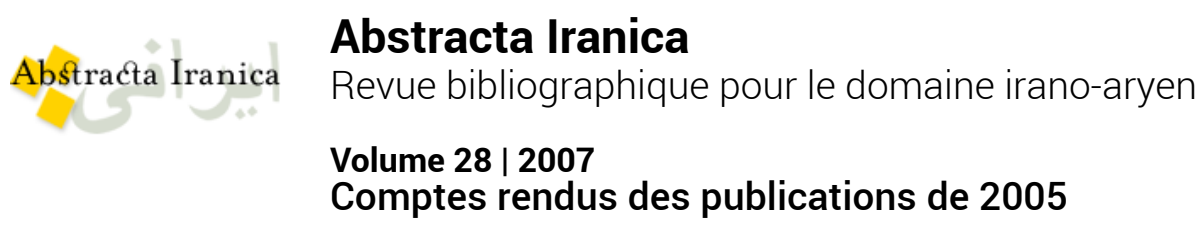

\title{
PRÉFACE - Abstracta Iranica 28 - 2005
}

Rémy Boucharlat, Poupak Rafii Nejad et Dominique Torabi

\section{(2) OpenEdition}

Journals

Édition électronique

URL : http://journals.openedition.org/abstractairanica/11772

DOI : 10.4000/abstractairanica. 11772

ISSN : 1961-960X

Éditeur :

CNRS (UMR 7528 Mondes iraniens et indiens), Éditions de l'IFRI

Édition imprimée

Date de publication : 15 mai 2007

ISSN : 0240-8910

\section{Référence électronique}

Rémy Boucharlat, Poupak Rafii Nejad et Dominique Torabi, «PRÉFACE - Abstracta Iranica 28 $2005 »$, Abstracta Iranica [En ligne], Volume 28 | 2007, mis en ligne le 18 septembre 2007, consulté le 25 septembre 2020. URL : http://journals.openedition.org/abstractairanica/11772 ; DOI : https:// doi.org/10.4000/abstractairanica. 11772

Ce document a été généré automatiquement le 25 septembre 2020.

Tous droits réservés 


\title{
PRÉFACE - Abstracta Iranica 28 - 2005
}

\author{
Rémy Boucharlat, Poupak Rafii Nejad et Dominique Torabi
}

1 Avec plus de 500 entrées, ce numéro 28 d'Abstracta Iranica offre un panorama plus large des publications 2005 et de quelques oublis de 2004. Certaines rubriques sont particulièrement fournies, reflétant la richesse des publications dans le domaine, mais aussi, soulignons-le, le travail des collaborateurs. Ceux-ci, toutes rubriques confondues, sont aujourd'hui près de 80 et viennent de divers pays, dont l'Iran. Ils seront certainement plus nombreux encore pour le numéro 29, actuellement en préparation. Nous faisons un effort particulier pour les rubriques insuffisamment couvertes.

2 La revue en ligne est devenue, nous l'espérons, un outil apprécié. L'indexation le rendra encore plus utile : les index actuellement mis en place sont en cours de révision et de complément. Par ailleurs, nous étudions la proposition qui nous a été faite par Persée (http://www.persee.fr) touchant la mise en ligne rétrospective des numéros 1 à 19. Le portail revues.org sera réservé aux numéros pour lesquels nous disposons de support électronique. L'ensemble de la rétrospective devrait aboutir fin 2008.

3 Rappelons que depuis qu'Abstracta Iranica est fabriqué en Iran, la revue dispose d'une version persane qui paraît régulièrement avec un an de décalage. Cette version a depuis cinq volumes un éditeur fixe, Tahouri, et un lectorat fidélisé. La visibilité en Iran est ainsi largement assurée.

4 Nous restons comme toujours à l'écoute de vos remarques et suggestions pour améliorer la revue. 
INDEX

Thèmes : Avant propos 